\title{
Developing Sustainably until 2030: A Case Study on a University Town, Kampar (Perak, Malaysia)
}

\author{
Siew-Mun Ang and Siew-Ching Ang
}

\begin{abstract}
Kampar in Perak, Malaysia, is expanding rapidly as a university town. In this paper, we first outlined the sustainable development plans from the Local Planner 2030 by the Kampar District Council, and some joint efforts from the University of Tunku Abdul Rahman (UTAR) as a green campus. We detailed some of the challenges involved and suggested some implementations. Lastly, we propose awareness, commitment and excitement (ACE) to propel the project forward. This paper is the ground work for our subsequent research projects. It is important, not only because it showcases a small developing town; it helps the community understand the practical challenges that we are facing in implementing sustainable plans.
\end{abstract}

Index Terms-Kampar, university town, sustainable development, Local Planner 2030.

\section{INTRODUCTION}

The Kampar town is an envisioned university town which has been revived from the diminishing tin mining industry. The town began to boom again since the establishment of a college (later upgraded to the status of University College as the Tunku Abdul Rahman University College or TARUC) and a Tunku Abdul Rahman University (UTAR) respectively [1]. Due to its draw on affordable, quality higher education, its low cost of living, and its strategic location between Kuala Lumpur and Pulau Pinang, the town is experiencing an unprecedented revitalization and urban growth. However, developing the town sustainably requires both vision and missions as well as careful planning.

Literatures abound on ways to develop sustainably [2]-[8]. The Brundtland Commission (1983) urged every nation to consider what is best for our future generations when designing and planning for new communities, housing projects and infrastructure development [9]. Since then, the United Nations [10], [11] had outlined 17 Sustainable Development Goals (SDG) to call for nations and cities of the world to participate in the effort to fight global warming until 2030 [12], [13].

Over 1,000 world mayors and local officials had pledged $100 \%$ renewable energy and $80 \%$ reduction in emission during the Habitat III Summit in Lyon, France [14], [15]. These cities include South America (Rio de Janeiro, Sao Paulo), North America (California, New York, Ontario,

Manuscript received October 30, 2017; revised December 23, 2017.

Siew-Mun Ang is with Tunku Abdul Rahman University, Malaysia (e-mail: angsiewmun@gmail.com).

Siew-Ching Ang is with The University of Texas at Austin, USA (e-mail: siew.ang@austin.utexas.edu).
Austin, Portland), Europe (Basque Country, Catalonia, Scotland), Australia (Adelaide) and China (nationwide).

While physical and economic development is usually synonymous with environmental degradation, Kampar is, fortunately, quite pristine. The Kampar District Council (2017) has laid out a comprehensive development plan (draft copy) named "Kampar District Local Planner 2030" which is aligned with the SDG even though it is not explicitly articulated sufficiently. There is another program called Local Agenda 21 (LA21) that was launched in 2015 to forge partnership between local authority, private sector and the local communities to work together towards sustainable development [16, 17].

Therefore, this paper hopes to raise awareness of such existing plans and calls for increased participation from all walks of life in the community as well as highlight existing challenges. Furthermore, we hope to fill in the gaps of existing planner by providing suggestions to overcome some of these challenges. In addition, this paper provides guidelines to young potential entrepreneurs and business ventures which are socially responsible; helping develop Kampar town can be economically beneficial, personally fulfilling and meaningful in the fight against global warming.

\section{BACKGROUND}

Once a tin mining town that had drawn mostly Chinese miners and businessmen here, this town had faced a 'dying' risk when the tin ore reserves diminished and the demand dwindled. Its young began to seek greener pasture elsewhere, leaving only the very young and the old residents in the town. Many people, especially the Chinese Malaysians, had likened Kampar town to 'a dying fish which was revived just in time'.

To the credit of the town elders, they invited the Malaysian Chinese Association (MCA), one of Malaysia's ruling BN coalition parties to come and establish UTAR [18].

Kampar district which is bordered by Pahang State (in the east), Kinta (north and west) and Batang Padang (in the south) was declared the $10^{\text {th }}$ district of Perak state in 2009 (see Fig. 1 [19] pp. 1-5).

It has an area of 66,997.5 hectare [20]. The Kampar district comprises of $54.5 \%$ forest, $33.0 \%$ agriculture, $4 \%$ waste land, $6.8 \%$ utility land (for housing, industry, business, social institutions, mixed development, infrastructure utility and transportation), $1.4 \%$ water elements, and $0.19 \%$ recreational land (Figure 2). The utility land is roughly $7.1 \%$ (including recreational spaces) in 2014, and the goal is to increase this portion to $15.2 \%$ by 2030 . Careful development plans are required to develop these areas sustainably 


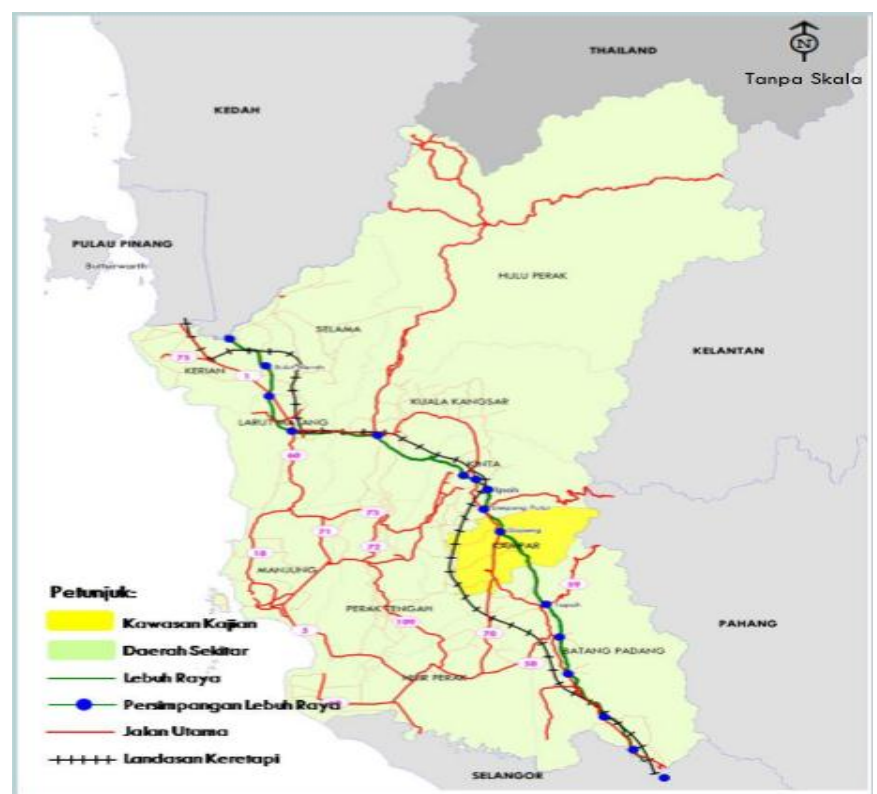

Fig. 1. Map of perak state and kampar district

Legend (from top to bottom):

Area of focus

Secondary area of focus

Highway

Highway junctions

Main Road

Railway

Source: Draft of Kampar District Local Planner 2030

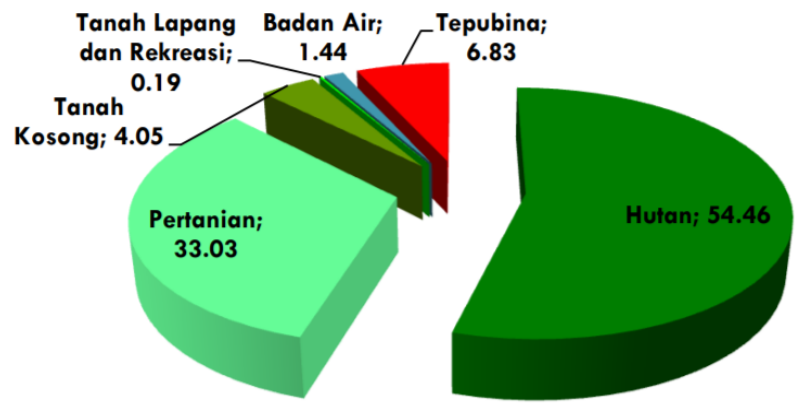

Fig. 2. Land use in Kampar district.

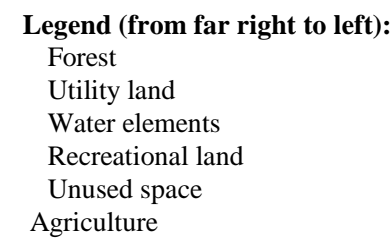

Source: Draft of Kampar District Local Planner 2030.

The Kampar town itself has a population of 90,313 in 2010 and 54.7 percent of the said population consists of Malaysians of Chinese descent, 31.8 percent Bumiputera (or literally 'sons of the soil' or local Malays and the indigenous people), 11.4 percent Malaysians of Indian descent, 0.2 percent other ethnics and 1.9 percent foreigners [21].

The town is divided into old town and new town but the whole of Kampar has been designated as a knowledge town or bandar berilmu (in the Malay Language) due to its close association with the education sector. Old town has remained with its original flavour of the late $19^{\text {th }}$-early 20 th centuries. On the other hand, the new town (Fig. 3), also known as the university town proper, is where most of the new communities are living. They are associated with the boom in the education enterprise where both TARUC and UTAR are located. In UTAR alone, the student population is about 11,000 excluding the UTAR (Sungai Long Campus).

This fact certainly has repercussions for the local environment, and its coping abilities due to increased traffic, increased consumption and also increased waste that comes together when a huge number of people converge in one place in a very short period of time. So far, how has this envisioned university town coped?

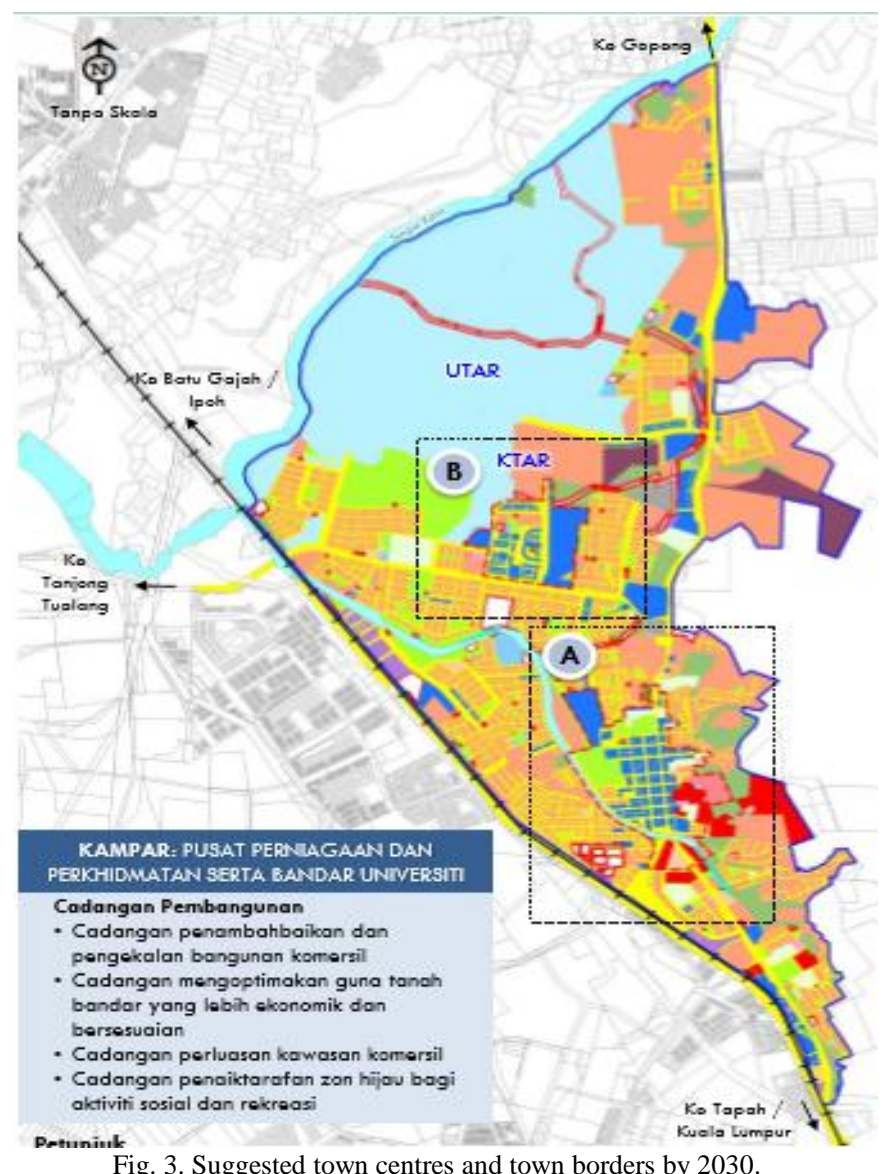

Fig. 3. Suggested town centres and town borders by 2030 .

Notations:

Region A: Suggested Kampar border in 2030

Region B: Suggested New Kampar Town border by 2030

Source: Draft of Kampar District Local Planner 2030

\section{EXISTING EFFORTS}

As an extension of the Planner's \#5th direction for the development of green neighbourhood and safety elements, the Kampar District Council has launched seven initiatives of green neighbourhood campaign in 2017 [22]. This campaign involved either joint efforts with UTAR Green Campus Committee in promoting the environmentally friendly activities on and around the campus or held separately by the Council itself. Among these activities are:

\section{A. Bird Conservation}

The university's main entrance passageway is built over a lake, the West Lake, which has an island that houses several species of birds. This area has been reserved as a natural habitat conservation area for on-going studies, monitoring, protecting and documenting the flow of dwindling bird species. In addition, it also helps encourage the knowledge and appreciation of birds and increase awareness of this 
imminent threat among the young generations. Moreover, it also promotes tourism among bird lovers such as members of the Audubon Society or the Malaysian Nature Society.

\section{B. Water and Energy Conservation}

The UTAR (Kampar Campus) toilets are installed with water conserving facets. Energy efficient light bulbs and movement sensors are used in all the toilets in the Kampar Campus. New constructions installed energy-efficient glass panels for open-floor concept and for natural lights into the buildings.

\section{Livable Space}

Walkable neighbourhoods. The newer housing development emphasizes clearer road signs, safe walkable spaces, benches along the path, spacious areas and recreational corners for young children and concert arenas. Even around campus, skilful landscaping and iconic pieces of art have been put in place a midst green lawns.

\section{Waste Management}

Recycling effort. At present, UTAR has three recycling bins for cans, plastics and paper; and a bin for 'general waste'. It is also important to note that soiled plastic packages are unfortunately still considered as 'general waste.' The Kampar District Council, via its recycling campaigns, has successfully achieved a 13 percent recycling rate in the areas [23].

"White coffin" campaign. One of the goals of this project is to discourage the use of white Styrofoam boxes within the campus. Cafeterias around the campus are encouraged to use biodegradable materials for take-out boxes, in line with the Local Agenda 21 (LA21). However, this campaign had brought some controversies to the company who manufactures and distributes polystyrene and plastic containers [24] [25].

\section{E. Sustainable Food}

Local farm projects. Volunteers are helping the neighbourhoods turn their unused yards into organic farming plots. This effort not only brings about nutritious foods to the tables in the neighbourhoods, it also increased awareness of efficient, productive land use, and cultivate a good habit for the young generations [26].

Composting. The district council, in collaboration with UTAR, began to call for food composting efforts among the communities in 2017 as part of the LA21 agenda. This effort is vital because the percentage of solid waste in the form of thrown food is 39.6 percent, the highest percentage of total solid waste collected in 2010 [27].

\section{F. Education}

Green course structures. Some courses in UTAR has built-in "planning events" that impact the world. For example, students and academic staff from the Department of Public Relations had planned a clean-up event as part of the course requirement; picking up trashes around waterfall areas in 2015. These students also organized another campaign to encourage cycling with lights on [28] [29]. Moreover, the Faculty of Engineering and Green Technology also consistently revised their curriculums to meet the demands of the changing fields.

\section{Challenges AND Suggestions}

Sustainable development, like all new concepts, faced numerous implementation challenges. Reference [30] outlined four main challenges in implementing the LA21 in Malaysia. These challenges revolved around budget deficiencies; lack of interests in partnership among the private sectors that only emphasizes profits; lack of "linkages" between policy makers and social organizations; and the lack of inter-agency collaborations. Other researchers [31] suggested another four challenges to the implementation of the LA21: the lack of political will; incompetence or inability to act; inefficiency and unrealistic investment goals. In this paper, the authors proposed the following suggestions to meet some of these challenges:

\section{A. Refundable Finances}

Financial resources. Budget is among the most important factors in ensuring the success of sustainable development. Refundable finance that yields investment and dividends which pays for public amenities is the next "new" concept. We propose that the Kampar District Council issues financial bonds to the public or private entrepreneurs. These bonds yield tax-free dividends to bond owners until the end of the maturation time, and allow for the re-issuing of these bonds at various sectors of the development. The legitimacy of the bonds and the public's confidence of the bonds are necessary for this program to be successful. In fact, there are other types of bonds, such as, the microcredit loans in Bangladesh suggested by Nobel Peace Prize winner, Muhammad Yunus, in which only the principals can be withdrawn, the dividends are reinvested to propel further social innovations [32].

\section{B. Planned Business Investment}

In order to attract green and socially responsible businesses, the town needs to offer tax-free incentives for the start-up, or incentive packages, such as financial loans at a low interest rate or tax-free for the first three years to attract private companies with plans to involve in green industries. In addition, these green industries should be planned development, in that, they are, by design, interconnected as primary and secondary industries to provide infrastructure support to each other.

For example, recycling industry not only requires hardware such as recycling bins and recycling centres, it also involves other infrastructures, such as, easy access to recycling bins (both in public areas and in every household); the willingness to recycle among consumers; timely and dependable bin collection; gathering of recycling disposals at the city level; transportation of these materials to recycling centres; various centres to recycle these materials into re-useable products; the marketing and demands of these recycled products; and last but not least, waste treatment and toxic material disposals from recycling to minimize pollution of the rivers and landfills. Thus, recycling projects should encourage young entrepreneurs to involve in one or many businesses along this line because any broken links in this chain of infrastructure will jeopardize the successful implementation of this project.

\section{Sustainable Housing Development}

Regulated Housing Plan. Outside of the campus, there is an abundance of uninhabited houses and shops. The home and shop owners are waiting for the right price to sell or to rent out the houses to the college students and the business community. 
These empty houses are wasted resources while the low-income residents could not afford a roof above their heads. Policies and regulations should be in place to document the intentions of the home buyers, i.e. whether it is for own use or for investment; in addition, limits should be in place as to the number of houses that one can own in Kampar. Incentives to build low-cost housing with green and safe neighbourhoods should be implemented.

\section{Sustainable Food}

Permaculture. In permaculture, the outputs of one system are served as inputs to another system to minimize wasteful resources. As an example, rain water is gathered to the farms for agricultural use; fish is raised in the farms, not only as produce; the fish waste, in turn, provides natural nutrients to the agricultural products. Kampar is particularly suited for permaculture because the average annual precipitation is 39.4 inches or about 100 centimetres [33]. Harvesting the rain water opens up many potential business ventures.

Composting. The District Council, local schools, college and university should continue to organize workshops on safe and correct composting to raise awareness of this movement, allow participants to gain familiarity to this concept, and also to teach the proper way to composting. The District Council should also consider subsidizing composting bins or rebate programs to encourage composting [34, 35].

\section{E. Education}

Young entrepreneurs. Cultivating a generation of entrepreneurs who are creative, innovative and socially responsible are necessary. UTAR should offer workshops and short courses on how to become a start-up to make it easy for young students to start their own businesses, especially 'green' businesses. This includes providing consultations and resources to address financial issues, legal issues, inventory and accounting issues, and moral support. In addition, meetings to share experiences, brainstorm sessions for ideas, and mentor-mentee programs are helpful to cultivate the spirit of innovators.

\section{F. Conservation}

Solar panels. The use of solar panels in houses should help reduce energy use, and if implemented successfully, can be adopted throughout the nation. This is in tandem with Dato' Seri Najib Razak, Malaysian Prime Minister's pledge to reduce our country's greenhouse gas emissions by $40 \%$ by the year 2020 [36, 37]. However, geomancers or Feng Shui masters generally agree that solar panels are 'unfriendly' or 'bad' in terms of feng shui for its owners. This technology will probably require some modifications in Asian homes due to cultural differences.

\section{G. Soft Skills as Lubricant to Project Success}

The following sections, though are not directly related to the SDG, are key to successful implementation of these projects. Among them are:

Partnerships and communication. Multi-way coordination between public and private partnerships are necessary to ensure the successful execution of green projects Concrete incentives are necessary for speedy results. Businesses in the new town comprise mainly food businesses, photocopier and stationery shops, computer cafés and laundry businesses. To encourage the use of biodegradable laundry detergent, for example, discount coupons or rebates should be issued by the District Council for such kind of detergents. The private supermarkets in the district should know in advance, and be ready with sufficient choices of biodegradable detergents when the rebates are launched for this project to be effective.

Leadership and commitment. Charismatic leadership and commitment to sustainable movements are important in mobilizing these projects; resolving creatively issues and obstacles that come along; finding extra resources and soliciting "buy-ins" from top-down and at the grass-root levels. Community services and meetings, accompanied with food, should be held regularly for questions and answers sessions.

Publicity. Advertisements in the newspaper and radio programs, town hall meetings, email circulations, posters and banners, multi-media outlets are good places to publicize the vision, mission and projects of the district council and/or the university. While environmentally-friendly efforts are being made at the university level, there are other on-going 'green' activities at the district council level. Publicity will hopefully attract more involvement from the community, especially young university students.

Participation and involvement. Kampar residents should be empowered and invigorated to attend special planning sessions, such as, monthly meetings called "Imagine Kampar", whereby residents get involved in shaping a vision for developing their community into a unique place suited for their children and their futures. These kinds of planning sessions should be held during the weekends and free delicious food should be offered as an incentive to encourage attendance. Austin, Texas has a similar program named "Imagine Austin" (2012) whereby its citizens are excited in shaping the future of their city sustainably [38].

\section{FURTHER RESEARCH DIRECTION}

Kampar must embrace this concept so that it will be a model for other university towns in Malaysia. As the town is expanding, this is the golden opportunity in terms of timing, to overcome whatever barriers that lies in front. Kampar must not stop in the face of challenges like so many other towns when it comes to innovations because we have the most creative pool of young people that should be channelled into creating something meaningful.

The authors suggest that we need Awareness, Commitment and Excitement (ACE) to propel these plans forward. This paper serves as the ground work for future research directions. In the future, our study involves designing a survey for creating awareness in sustainable development among the UTAR students and Kampar residents.

\section{ACKNOWLEDGMENT}

We would like to say "Thank you" to Mr A.H. Muhamad Faiz, assistant town planning officer to the Kampar District Council for providing us with a digital copy of the Kampar District Local Planner 2030 and also Mr Seng-Chee Goh, environmental officer to the Kampar District Council, for the brochures on its 'green' activities. 


\section{REFERENCES}

[1] Kampar District Local Planner 2030 (n.d.). Kampar: Kampar District Council.

[2] H. Girardet, Creating a Sustainable Adelaide, Adelaide: Government of South Australia, 2013.

[3] J. K. Hall, G. A. Daneke, and M. J. Lenox, "Sustainable development and entrepreneurship: Past contributions and future directions," Journal of Business Venturing, vol. 25, no. 5, pp. 439-448, 2010.

[4] S. M. Pires, T. Fidélis, and B. Ramos, "Measuring and comparing local sustainable development through common indicators: Constraints and achievements in practice," Cities, vol. 39, pp. 1-9, 2014.

[5] U. Pupphachai and C. Zuidema, "Sustainability indicators: A tool to generate learning and adaption in sustainable urban development," Ecological Indicators, no. 72, pp. 784-793, 2017.

[6] E. F. Schumacher, Small is Beautiful, London: Vintage Books, 1993.

[7] M. Braungart and W. McDonough, Cradle to Cradle: Re-Making the Way We Make Things, London: Vintage Books, 2009.

[8] D. Dumanoski, The End of the Long Summer, New York: Crown Publishers, 2009.

[9] Brundtland Report. (1987). [Online]. Available: https://www.are.admin.ch/are/en/home/sustainable-development/inte rnational-cooperation/2030agenda/un-_-milestones-in-sustainable-de velopment/1987--brundtland-report.html

[10] COP21. (Dec 2015). Paris Agreement. [Online]. Available: http://www.cop21 paris.org/

[11] United Nations. (2017). Sustainable development. [Online]. Available:

http://www.un.org/en/sections/what-we-do/promote-sustainable-dev elopment/index.html

[12] Transforming Our World: The 2030 Agenda for Sustainable Development (2017). [Online]. Available: https://sustainabledevelopment.un.org/post2015/transformingourwor ld

[13] D. Griggs, M. Stafford-Smith, O. Gaffney, J. Rockstrom, C. Ohman, P. Shyamsunar, W. Steffen, G. Glaser, N. Kanie, and I. Noble. (2013). Policy: Sustainable Development Goals for People and Plane. [Online]. Available: https://www.nature.com/articles/495305a

[14] G. Scruggs, (2015). With Paris City Hall Declaration, world mayors throw down gauntlet on climate. [Online]. Available: http://citiscope.org/habitatIII/news/2015/12/paris-city-hall-declaratio n-world-mayors-throw-down-gauntlet-climate

[15] UN-Habitat GHSR. (2009). Planning Sustainable Cities. London: Earthscan.

[16] Bima Buwana (n.d.). Local Agenda 21: A Case Study on Malaysia. [Online].

Available: https://www.scribd.com/doc/14620188/Local-Agenda-21-A-Case-St udy-on-Malaysia

[17] N. Nabila, A. A. and M.O. Mariana, (2012). Local Agenda 21: Action Plan for Sustainable Development - Case Study of Shah Alam. [Online].

Available: http://irep.iium.edu.my/25948/2/UMRAN_-_LA21_ACTION_PLA N.pdf

[18] The Star Online (January 11, 2003). Gratitude Theme for UTAR Do. [Online].

Available: https://www.thestar.com.my/news/nation/2003/01/11/gratitude-them e-for-utar-do/

[19] Kampar District Local Planner 2030 (n.d.). Kampar: Kampar District Council.

[20] Kampar District Local Planner 2030 (n.d.). Kampar: Kampar District Council.

[21] Kampar District Local Planner 2030 (n.d.). Kampar: Kampar District Council.

[22] Kampar District Council (2017). [Online]. Available: http://www.mdkampar.gov.my/

[23] Kampar District Council (2017). [Online]. Available: http://www.mdkampar.gov.my/

[24] T. Naufal and T. M. (2017). Case Study 2: The 'White Coffin' Dilemma. [Online]. Available: https://www.scribd.com/document/150130757/Case-Study-2-White-
Coffin

[25] Kampar District Council (2017). [Online]. Available: http://www.mdkampar.gov.my/

[26] Kampar District Council http://www.mdkampar.gov.my/

(2017). [Online]. Available:

[27] Closing Ceremony of PR Campaign 2015 (2015). [Online]. Available: http://www.utar.edu.my/econtent_sub.jsp?fcatid=16\&fcontentid=25 572

[28] N. Nabila, A. A. and M. O. Mariana. Local Agenda 21: Action Plan for Sustainable Development - Case Study of Shah Alam. [Online]. Available:

http://irep.iium.edu.my/25948/2/UMRAN_-_LA21_ACTION_PLA N.pdf

[29] H. Singh. (2008). Development through decentralization and good governance: The China and Malaysia experiences in implementing Local Agenda 21. Presented in Facing the China Challenge 2008, International Conference.

[30] M. M. Osman, R.N. S. Rashid, and N. Ahmad, (2008). "Local agenda 21 in Malaysia: Issues and problems faced by the stakeholder in the participation process," presented in Ecocity World Summit 2008 Proceedings.

[31] M. Yunus, (2017). A World of Three Zeros. The New Economics of Zero Poverty, Zero Unemployment, and Zero Net Carbon Emissions. New York, NY: Acapella Books.

[32] World Weather and Climate Information (2016). [Online]. Available: https://weather-and-climate.com/average-monthly-precipitation-Rain fall-inches,kampar-perak-my,Malaysia

[33] Kampar District Council (2017). [Online]. Available: http://www.mdkampar.gov.my/

[34] Tan Peck Leong (2001). Awareness and Attitude towards Environmental Issues: A Case Study in Section 17, Petaling Jaya, Malaysia. Master of Applied Statistics Thesis. University of Malaya. Retrieved from University of Malaya Main Library.

[35] D. Chance and R. Ahmad. (2009). Malaysia PM to Offer CO2 Reductions in Copenhagen. [Online]. Available: http://www.scientificamerican.com/article.cfm?id=malaysia-pm-to-o ffer-co2

[36] A. Netto, (2009). Climate Change: Copenhagen Talks Create Hardly A Ripple in Malaysia. [Online]. Available: http://www.ipsnews.net/news.asp?idnews=49744

[37] Imagine Austin. (2012). [Online]. Available: http://austintexas.gov/imagineaustin

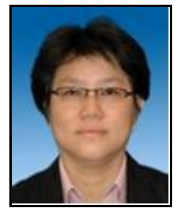

Siew-Mun Ang holds an MPhil in sociology and politics of Development from Cantab, U.K. in 1993, and a BA (with honors) in history from the University of Malaya, Malaysia.

She is a senior lecturer at the University of Tunku Abdul Rahman (UTAR, Kampar Campus) since 2008.

Ms. Ang is a life member of the Malaysian Social Science Association (PSSM), a member of IEDRC and IACSIT as well as a member of The Australian Sociological Association (TASA).

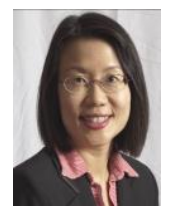

Siew-Ching Ang has a Ph.D. in quantitative psychology from the University of Oklahoma in 2008. She is a research associate at the University of Texas at Austin since 2011.

Her research encompasses studying the impact of credit transfer mechanisms on subsequent course student success, curriculum redesigns and majors transfer. She also explored health issues, such as, children obesity, vaccinations and Behavioral Risk Factors and Surveillance Survey (BRFSS).

In 2012, Dr. Ang received the best poster award at a national conference (Association of Institutional Research). In 2014, she received further training at the SAS Learning Analytics workshop in New York, won a scholarship to attend the Learning Analytics Summer Workshop at the Harvard Graduate School of Education, and a visiting scholar at Civitas Learning in 2015. 